Research Article

\title{
SDF-1 $\alpha$ Facilitates Mesenchymal Stem Cells to Induce Regulatory B Cell Differentiation from Patients with Immune Thrombocytopenia
}

\author{
Zhe Chen $\mathbb{D},{ }^{1,2,3}$ Shufen Zhou $\mathbb{D}^{1,2,3}$ Jianyun $\mathrm{Li} \mathbb{D},{ }^{4}$ Hui $\mathrm{Li} \mathbb{D},{ }^{1,2,3}$ Can Huang $\mathbb{D}^{4},{ }^{4}$ \\ Qin Guo $\mathbb{D},{ }^{1,2,3}$ Tiantian Zhang $\mathbb{D},{ }^{1,2,3}$ Bingya Yang $\mathbb{D},{ }^{5}$ Chuanqing Tu $\mathbb{D}^{4}$, \\ and Chengshan Guo $\mathbb{D}^{1,2,3}$ \\ ${ }^{1}$ Department of Rheumatology and Immunology, Southern Medical University Affiliated Shenzhen Baoan Hospital, \\ Shenzhen, China \\ ${ }^{2}$ Department of Rheumatology and Immunology, Guangdong Medical University Shenzhen Baoan Clinical College, \\ Shenzhen, China \\ ${ }^{3}$ Department of Rheumatology and Immunology, Shenzhen University Second Affiliated Hospital, Shenzhen, China \\ ${ }^{4}$ Department of Hematology, Guangdong Medical University Shenzhen Baoan Clinical College, Shenzhen, China \\ Spunolin Biotechnology Co., Ltd., Shenzhen, China
}

Correspondence should be addressed to Chengshan Guo; guochengshan1@163.com

Received 7 August 2021; Accepted 11 October 2021; Published 8 November 2021

Academic Editor: Dunfang Zhang

Copyright (C) 2021 Zhe Chen et al. This is an open access article distributed under the Creative Commons Attribution License, which permits unrestricted use, distribution, and reproduction in any medium, provided the original work is properly cited.

B cells play a central role in the pathogenesis of immune thrombocytopenia (ITP) by participating in humoral immunity. Meanwhile, regulatory B cells (Bregs), one subset of B cells, express negative regulatory effect on ITP. Mesenchymal stem cells (MSCs) have been demonstrated in the ability to induce immunosuppression, and stromal cell-derived factor-1 $\alpha$ (SDF-1 $\alpha$ ) plays an important role in the migration and survival of MSCs. To investigate the mechanism of SDF- $1 \alpha$ in controlling umbilical cord-derived MSCs (UC-MSCs) in inducing regulatory B cell differentiation of patients with ITP, we reconfirmed that SDF- $1 \alpha$ promotes the proliferation of MSCs at the low doses of $0.05 \mu \mathrm{g} / \mathrm{mL}$ and $0.1 \mu \mathrm{g} / \mathrm{mL}$ but inhibits the proliferation and promotes the apoptosis of UC-MSCs at the high doses $0.5 \mu \mathrm{g} / \mathrm{mL}$ and $1 \mu \mathrm{g} / \mathrm{mL}$; when UC-MSCs are cocultured with SDF- $1 \alpha$ at $0.1 \mu \mathrm{g} / \mathrm{mL}$, the decreased proportion of CD $19^{+} / \mathrm{CD} 24^{\text {hi }} / \mathrm{CD} 38^{\mathrm{hi}}$ cells and IL-10-producing B cells (B 10 cell), considered as the Breg subset from ITP significantly enhanced, and the content of IL-10 in the supernatant is also obviously increased. The proportion of Bregs and the IL-10 secretion could be further promoted by the UC-MSCs treated with $0.1 \mu \mathrm{g} / \mathrm{mL}$ SDF- $1 \alpha$, which could also promote the miRNA-133 expression of UC-MSCs in an exosomedependent manner; moreover, while the UC-MSCs were transfected with the miR-133 inhibitor, the proportion of induced Bregs decreased obviously when cocultured with peripheral blood mononuclear cells (PBMCs) of ITP. We conclude that UC-MSCs could effectively enhance the decreased proportion of Bregs from ITP; at appropriate concentrations, SDF- $1 \alpha$ may promote the proliferating and survival ability of UC-MSCs and improve the production of Bregs induced by UCMSCs through controlling miRNA-133 expression in the exosomes.

\section{Introduction}

Immune thrombocytopenia (ITP) is an immune-mediated acquired disease characterized by a persistent or transient decrease of platelet count. Traditionally, B cells have been thought to contribute to the pathogenesis of this autoimmune disease through platelet-specific autoantibody production. In fact, B cells play a central role in the pathogenesis of ITP, because it not only generates autoantibody participating humoral immunity but also acts as antigen presenting 
cells (APCs) to enhance immune reaction and even directly secretes some cytokines leading to platelet destruction [1]. However, there is another subset capable of negative immune regulation named regulatory $\mathrm{B}$ cells (Bregs) to maintain the immune homeostasis under normal physiological conditions or in autoimmune diseases [2,3]. Unfortunately, Bregs were found expressing dysregulation in ITP [4], so promoting the differentiation and expanding the role of Bregs in immunoregulation is very important. Mesenchymal stem cells (MSCs) have been investigated in cell-based therapies because of the remarkable regenerative properties and the ability to induce immunosuppression via interaction with cells from both the innate and adaptive immune systems [5-11]. It is very interesting that MSCs can induce Bregs and regulatory $\mathrm{T}$ cell (Treg) production [12-15], as well as suppress the effector B cells [16-18]. However, the mechanism of MSCs in inducing Bregs of ITP still remains unclear, and in particular, there still remain many difficulties for MSCs in clinical treatment because of the obstacles in migration and survival.

Stromal cell-derived factor- $1 \alpha$ (SDF- $1 \alpha)$ is a well-known major chemotactic factor induced by hypoxia and ischemic tissue and is critical for the process involving MSC organspecific homing in injury tissue through interaction with its cognate receptor CXC chemokine receptor 4 (CXCR4) on the surface of MSCs [19-21]. Furthermore, it is valuable to explore whether SDF- $1 \alpha$ is involved in the immunoregulation of MSCs, especially the mechanism in inducing Breg differentiation. The immunological properties of MSC exosomes to modulate the immune system have been provided [22]. As miR-133 has been shown to influence the MSC function [23], we thus hypothesized that SDF- $1 \alpha$ may change the miR-133 expression and enhance the ability of MSCs to promote Bregs by means of exosomes. Due to noninvasive and easy access of the tissue origins from human delivery wastes when getting the umbilical cord (UC), the UC derived-MSCs (UC-MSCs) exhibit a higher degree of multipotency and a stronger ability to self-renew than bone marrow-derived MSCs (BM-MSCs) or adipose tissuederived MSCs (AD-MSCs) [7, 8], and we used UC-MSCs to investigate their effect on inducing Breg differentiation ITP and the mechanism of SDF- $1 \alpha$ in controlling proliferation, apoptosis, and regulatory function of UC-MSCs and proved that SDF- $1 \alpha$ promotes the expression of miR-133 in MSCs to facilitate their ability in an exosome-dependent manner. The aim of the research is to provide a potential approach in the management of ITP.

\section{Materials and Methods}

2.1. Patients and Controls. Between January 2019 and June 2020, 18 patients (7 males and 11 females, age range 19-71 years, median age 29.5 years) with active ITP in the Shenzhen Baoan Hospital affiliated to the Southern Medical University and Guangdong Medical University Shenzhen Baoan Clinical College were enrolled. All of the cases fulfilled the diagnosis criteria of ITP as previously described $[24,25]$, and the inclusion criteria are in accordance with these diagnosis criteria. Patients' platelet counts ranged from
1 to $74 \times 10^{9} / \mathrm{L}$, with a median count of $13 \times 10^{9} / \mathrm{L}$. None of them had received any corticosteroid or immunosuppressive therapy within the 3 months prior to sampling. Patients with diabetes, hypertension, cardiovascular diseases, pregnancy, active infection, or connective tissue diseases, such as systemic lupus erythematosus, were excluded. The parallel consisted of 10 healthy adult volunteers ( 2 males and 8 females, age range $20-55$ years, median 31.0 years), whose platelet counts ranged from 136 to $393 \times 10^{9} / \mathrm{L}$, with the median count of $227 \times 10^{9} / \mathrm{L}$.

2.2. UC-MSC Isolation, Culture, and Differentiation. Wharton's Jelly from the umbilical cord was cut into $1 \mathrm{~mm}^{3}$ pieces and digested with $1 \mathrm{mg} / \mathrm{mL}$ collagenase II (Sigma, USA) diluted in PBS at $37^{\circ} \mathrm{C}$ for $9 \mathrm{~h}$. The acquired cell suspension was washed with PBS for three times and seeded in Dulbecco's modified Eagle's medium (DMEM) with $10 \%$ fetal calf serum (Gibco-BRL, USA), $2 \mathrm{mmol} / \mathrm{L}$ glutamine, antibiotics (100 U/mL penicillin, $100 \mathrm{mg} / \mathrm{mL}$ streptomycin), and $10 \mathrm{ng} / \mathrm{mL}$ basic fibroblast growth factors (Gibco-BRL). The cells were cultured at $37^{\circ} \mathrm{C}$ in an atmosphere of $5 \% \mathrm{CO}_{2}$. The adherent cells were cultured to confluence. Culture medium was changed every week, and the cells were treated with $0.25 \%$ trypsin (Gibco-BRL) for subculture. The cells $\left(3 \times 10^{5}\right)$ at passage 3 (Supplementary $1 \mathrm{~A}$ ) were seeded in 12 -well plates and cultured to reach about $90 \%$ confluence for identifying the differentiation property of the cells from UC [26-28]. Briefly, for the osteogenic differentiation medium: DMEM complete medium containing $10 \mathrm{nM}$ dexamethasone, $100 \mu \mathrm{M}$ l-ascorbic acids, $10 \mathrm{mM} \beta$-glycerophosphate I, and 5\% FBS; for adipogenic differentiation medium: DMEM complete medium containing $0.5 \mathrm{mM} 3-$ isobutyl-1-methylxanthine, $60 \mu \mathrm{M}$ indomethacin, $10 \mathrm{nM}$ dexamethasone, $10 \mu \mathrm{g} / \mathrm{mL}$ insulin, and 5\% FBS. Oil Red O was used for detection of differentiation potency to adipocytes and alkaline phosphatase staining for detection of differentiation potency to osteocytes (Supplementary 1B-1C). The staining results were analyzed with a microscope.

2.3. FACS Analysis. The phenotypes of UC-MSCs incubated with labelled antibodies were analyzed using FACSCalibur (BD Biosciences, USA), positive cells were counted, and the signals for the corresponding immunoglobulin isotypes were for contrasts (Supplementary 1D). The antibodies included FITC-labelled anti-CD44, PE-labelled anti-CD105, PClabelled anti-CD29, APC-labelled anti-CD34, and APC-cy7labelled anti-CD45 (eBioscience, CA, USA). The markers of Bregs were detected by the following antibodies: CD19, CD24, CD38, and IL-10 (eBioscience, CA, USA).

2.4. MSC Viability and Apoptosis Assays. Referring to the method described [29], MSCs $\left(2.0 \times 10^{5}\right)$ were seeded in 24 -well plates with medium containing SDF-1 $\alpha$ (Sigma, USA) in different concentrations $(0 \mu \mathrm{g} / \mathrm{mL}, 0.05 \mu \mathrm{g} / \mathrm{mL}$, $0.1 \mu \mathrm{g} / \mathrm{mL}, 0.5 \mu \mathrm{g} / \mathrm{mL}, 1.0 \mu \mathrm{g} / \mathrm{mL})$. Cell proliferation was measured from 0 to 4 days successively using a 3-(4,5dimethylthiazol-2-yl)-2,5-diphenyltetrazolium bromide (MTT, Sigma, USA) assay. MSC apoptosis was assessed using Annexin V-APC-Propidium Iodide (Annexin V/PI, 
Sproutbios, Shenzhen, China) staining with FACS after $48 \mathrm{~h}$. Importantly, we could select an appropriate concentration of SDF- $1 \alpha$ to promote the viability and immunoregulation function of MSCs at this experimental procedure.

2.5. B Cell Isolation. Peripheral blood mononuclear cells (PBMCs) were isolated by Ficoll-Hypaque gradient centrifugation (Haoyang, China). B cells were selected by the magnetic-activated cell sorting (MACS) cell separation system (Miltenyi Biotec, Germany) using anti-CD19 microbeads. Briefly, PBMCs were incubated for $30 \mathrm{~min}$ at room temperature with the microbeads conjugated with antiCD19 antibody. Then, the incubated PBMCs were transferred into the LS column placed on the magnetic separator. The unlabelled cells would be discarded after passing through the magnetic field and washing by the buffer. Lastly, the cells combining with microbeads were eluted through the column and collected.

2.6. MSC and PBMC Coculture. MSCs cocultured with PBMCs were set up in 12-well plates. Briefly, in the control groups, MSCs were cocultured with PBMCs $\left(2 \times 10^{5}\right.$ cells/well) at the ratio of $1: 1,1: 10$, and $1: 100$ for $48 \mathrm{~h}$. Based on the different effects of different SDF- $1 \alpha$ concentrations on MSCs from the above procedure, SDF- $1 \alpha$ of $0.1 \mu \mathrm{g} / \mathrm{mL}$ was chosen to stimulate MSCs $\left(2 \times 10^{5}\right.$ cells/well $)$ for $24 \mathrm{~h}$, then the stimulated MSCs were also cocultured with PBMCs at the ratio of $1: 1$, for $48 \mathrm{~h}$ in the experimental groups. The culture medium was supplied with $25 \mathrm{ng} / \mathrm{mL}$ of CD40L and $200 \mathrm{U} / \mathrm{mL}$ of IL-2 (PeproTech, USA). Add $50 \mathrm{ng} / \mathrm{mL}$ of PMA, $500 \mathrm{ng} / \mathrm{mL}$ of Ionomycin, and $2 \mu \mathrm{M}$ of Monensin (Sigma, USA) into the coculture system during the last 6 hours. After coculture, the Bregs were collected and stained with anti-CD19, anti-CD24, anti-CD38, and anti-IL-10; then, the Breg generation was examined by using flow cytometry.

2.7. Enzyme-Linked Immunosorbent Assay (ELISA). MSCs were coculture with the B cells isolated from PBMCs. The supernatant level of IL-10 in the medium was measured by ELISA (kits from R\&D Systems Inc., USA) after being cultured for $48 \mathrm{~h}$. In another group, after being incubated with $0.1 \mu \mathrm{g} / \mathrm{mL}$ of SDF- $1 \alpha$ for $24 \mathrm{~h}$, the MSCs were cocultured with B cells for $48 \mathrm{~h}$, and the supernatant level of IL-10 in the medium was also detected. All reagents, standards, samples, and experimental procedures were prepared according to the manufacturer's instructions. Finally, $50 \mu \mathrm{L}$ of stop solution was added to each well, and absorbance was detected at $450 \mathrm{~nm}$ with an automatic ELISA analysis apparatus.

2.8. Western Blotting. MSCs were washed with ice cold PBS and harvested in lysis buffer containing proteinase inhibitors. Proteins were separated on sodium dodecyl sulfate polyacrylamide gels (SDS-PAGE, Zeye, Shanghai, China) and transferred onto polyvinylidene difluoride membranes. The membranes were blocked with TBS-T buffer containing $5 \%$ nonfat dry milk and incubated overnight at $4^{\circ} \mathrm{C}$ with primary antibodies against cyclin A, cyclin B, Bax, cleaved caspase-3, and GAPDH (Heidelberg, Germany), followed by washing and incubating with horseradish peroxidase(HRP-) conjugated secondary antibodies for $2 \mathrm{~h}$ at room temperature. The chemiluminescence signal was detected by the use of the ChemiDoc ${ }^{\mathrm{TM}}$ MP System (Bio-Rad Laboratories, USA).

2.9. Reverse Transcription-Quantitative Polymerase Chain Reaction $(R T-q P C R)$. MSCs $\left(2.0 \times 10^{5}\right)$ were seeded in 12 well plates, with the medium containing $0.1 \mu \mathrm{g} / \mathrm{mL}$ of SDF$1 \alpha$ or AMD3100 ( $5 \mu \mathrm{M}$, Sigma), the CXCR4-specific antagonist. After the MSCs were cultured for $24 \mathrm{~h}$, total RNA was extracted from MSCs using a TRIzol reagent (Invitrogen, USA) according to the manufacturer's instructions. Isolated RNA was reverse-transcribed using a PrimeScript RT Reagent Kit (TAKARA, Japan). The quantity of miR-133 was detected by RT-qPCR using the FastStart Universal SYBR Green Master (Roche, Switzerland); the primers (Shengong, China) used for miR-133 are as follows: sense, $5^{\prime}$-TTGGTCCCC TTCAACC-3'; anti-sense, $5^{\prime}$-GTGCAG GGTCCGAGGT- ${ }^{\prime}$. U6 was used as an internal standard, and the quantifications of the relative gene were calculated by the comparative Ct method: $\Delta \Delta \mathrm{CT}=\Delta \mathrm{CT}$ (test) $-\Delta \mathrm{CT}$ (calibrator).

2.10. Transient Transfection. MSCs $\left(1.0 \times 10^{4}\right)$ were seeded in 12-well plates and transfected with miR-133 inhibitor or negative control using Lipofectamine 2000 (Invitrogen, USA) according to the manufacturer's protocols. The transfected MSCs were treated with $0.1 \mu \mathrm{g} / \mathrm{mL}$ SDF- $1 \alpha$ for $24 \mathrm{~h}$, and then, cell vitality, cell apoptosis, and cocultured assay were performed. The following primers (Shengong, China) were used for the transfection: miR-133 inhibitor primers, 5' -ACAGCTGGTTCTTGGGACCAAACAGCTGGTTCTT GG-GACCAAACAGCTGGTTCTTGGGACCAAACAG CTGGTTCTTGGGACCAAACAGCTGGTTCTTGGGAC CAA-3'; NC primer, 5' ${ }^{\prime}$-TTCTCCGATGCGTCACGTTTT TCTCCGATGCGTCACGTTTTTCTCCGATGCGTCAC GTTTTTCTCCGATGCGTCACGTTTTTCTCCGATGC GTCACGTTTTTCTCCGATGCGTCACGTTT-3' .

2.11. The Isolation of Exosomes from MSCs. The MSCs $\left(1.0 \times 10^{5}\right)$ were cultured in $10 \mathrm{~cm}$ dishes. When the cell density of MSCs is $70 \%$, replenish with $10 \mathrm{~mL}$ fresh complete DMEM medium with exosome-depleted FBS. MSCs were cultured for another 24 hours, then the medium was collected, centrifuged at $300 \mathrm{~g}$ for 5 minutes under $4^{\circ} \mathrm{C}$ to deplete cells, and then centrifuged at $600 \mathrm{~g}$ for 5 minutes under $4^{\circ} \mathrm{C}$ to deplete debris. To further deplete debris, the medium will be centrifuged at $1000 \mathrm{~g}$ for 15 minutes under $4^{\circ} \mathrm{C}$. Further, the medium was collected and centrifuged at $100,000 \mathrm{~g}$ for 2 hours under $4^{\circ} \mathrm{C}$; the exosomes will be visible as a pellet at the bottom of the tube. The exosome-depleted medium will also be collected for further experiments. The pellet was washed with PBS and centrifuged at $100,000 \mathrm{~g}$ for another 2 hours under $4^{\circ} \mathrm{C}$. The pellet was collected and resuspended in $200 \mu \mathrm{L}$ PBS. The exosomes can be stored under $4^{\circ} \mathrm{C}$ for one week. To test the effects of MSC-derived exosomes on B cells, $20 \mu \mathrm{L}$ exosomes will be added into $1 \mathrm{~mL}$ medium to culture B cells. 
2.12. Statistical Analysis. Experimental data were analyzed using SPSS version 21.0 (SPSS Munich, Germany). Values are presented as means $\pm \mathrm{SD}$. Statistical analysis was performed using one-way variance analysis to compare data among three or more groups and Student's paired $t$ test to compare data between two groups, the Dunnett $t$ method was used for multiple comparisons.

\section{Results}

3.1. Characterization of Human UC-MSCs. The cells exhibited a spindle-shape and adhered to the culture dishes closely at passage 3 . The cells expressed positive for CD105, CD44, and CD49, but negative for CD34 and CD45 [30]. The differentiation potential of UC-MSCs was demonstrated by the differentiation into adipocytes and osteoblasts (Supplementary 1).

3.2. MSCs Can Promote Breg Differentiation from Peripheral $B$ Cells of ITP. Compared to normal controls, lower percentages of both the $\mathrm{CD} 19^{+} \mathrm{CD} 24^{\text {hi }} \mathrm{CD} 38^{\text {hi }} \mathrm{B}$ cells $(8.12 \pm 1.21 \%$ vs. $2.40 \pm 0.62 \%)$ and IL-10-producing B cells $(6.02 \pm 0.44 \%$ vs. $2.11 \pm 0.35 \%$ ) were found in B cells from the ITP patient (Figures 1(a) and 1(b), Supplementary 2), revealing the impairment of Bregs in ITP patients. To determine whether UC-MSCs could induce the Breg generation from peripheral B cells of ITP, we found that the MSCs significantly promoted the generation of $\mathrm{CD} 19^{+} \mathrm{CD} 24^{\text {hi }} \mathrm{CD} 38^{\text {hi }} \mathrm{B}$ cells $(2.01 \pm 0.46 \%$ vs. $5.42 \pm 0.53 \%)$ and IL-10-producing B cells $(2.44 \pm 0.58 \%$ vs. $5.78 \pm 0.86 \%$ ) (Figures 1(c) and 1(d)).Cocultured MSCs with $\mathrm{B}$ cells can increase the IL-10 level, especially at the ratio of $1: 1(180.05 \mathrm{pg} / \mathrm{mL} \pm 23.252 \mathrm{pg} / \mathrm{mL})$. Meanwhile, the lower concentration $(35.231 \pm 8.601 \mathrm{pg} / \mathrm{mL})$ of IL-10 was detected, when the MSCs were cultured individually (Figure 1(e)). These data suggest that human UC-MSCs have the ability to regulate Breg differentiation.

3.3. SDF-1 $\alpha$ Affects the Proliferation, Apoptosis, and Survival of UC-MSCs. When UC-MSCs were incubated with different concentrations of SDF- $1 \alpha$, the results showed that, compared to the control, the cell proliferating curve of MSCs increased obviously at the concentrations of $0.05 \mu \mathrm{g} / \mathrm{mL}$ and $0.1 \mu \mathrm{g} / \mathrm{mL}$ of SDF- $1 \alpha$ (Figure 2(a)) but had no difference in MSC viability $(98.53 \pm 10.06 \%$ vs. $99.71 \pm 15.13 \%$ vs. $97.42 \pm 16.70 \%)$ (Figure 2(b)) and apoptotic rate $(2.19 \pm 0.48 \%$ vs. $2.37 \pm$ $0.77 \%$ vs. $1.96 \pm 0.64 \%$ ) (Figure 2(c)). However, compared to the control, the higher concentrations of SDF- $1 \alpha$ $(0.5 \mu \mathrm{g} / \mathrm{mL}$ and $1.0 \mu \mathrm{g} / \mathrm{mL})$ could inhibit the proliferation (Figure $2(\mathrm{a}))$ and the viability $(98.53 \pm 10.06 \%$ vs. $76.81 \pm$ $8.90 \%$ vs $65.35 \pm 9.12 \%$ ) (Figure 2(b)) but could increase the apoptotic rate $(2.19 \pm 0.48 \%$ vs. $16.14 \pm 3.02 \%$ vs. $23.37 \pm$ 4.5) (Figure 2(c)) of UC-MSCs.

Western blotting was performed to investigate the cell cycle regulatory proteins (cyclin $\mathrm{A} 1 / \mathrm{B} 1$ ) and apoptosisrelated proteins (cleaved caspase-3/Bax). SDF- $1 \alpha$ at the lower concentrations could increase the expression of cyclin A1/B1 (Figure 2(d)); however, the expression of cleaved caspase-3/Bax could be promoted at the higher concentrations
(Figure $2(\mathrm{e})$ ). So, we select $0.1 \mu \mathrm{g} / \mathrm{mL}$ of SDF- $1 \alpha$ for the next related research.

3.4. SDF-1 $\alpha$ Is Involved in the Regulation of UC-MSCs on the Differentiation of Bregs in ITP. After being cocultured with the UC-MSCs, the percentage of $\mathrm{B} 10$ and $\mathrm{CD} 19^{+} /-$ CD $24^{\text {hi }} / \mathrm{CD} 38^{\text {hi }}$ cells in CD $19^{+}$B cells of ITP elevated $(2.61 \pm 0.48 \%$ vs. $5.48 \pm 0.73 \%$ and $1.52 \pm 0.38 \%$ vs. $5.18 \pm$ $0.85 \%$ ) signally (Figures 3(a) and 3(b), Supplementary 3).

Furthermore, compared to the non-SDF- $1 \alpha$-stimulated UC-MSC group, B10 and $\mathrm{CD} 19^{+} / \mathrm{CD} 24^{\mathrm{hi}} / \mathrm{CD} 38^{\text {hi }}$ cells increased much more $(5.48 \pm 0.73 \%$ vs. $6.53 \pm 0.49 \%$ and $5.18 \pm 0.58 \%$ vs. $6.58 \pm 0.49 \%)$ when the UC-MSCs were incubated with $0.1 \mu \mathrm{g} / \mathrm{mL}$ of SDF- $1 \alpha$ (Figures 3(a) and 3(b), Supplementary 3).

Compared to the cultures of $\mathrm{CD}_{19}{ }^{+} \mathrm{B}$ cells $(192.67 \pm 18.93 \mathrm{pg} / \mathrm{mL})$ and UC-MSCs $(42.38 \pm 5.725 \mathrm{pg} / \mathrm{mL}$ ) singly, the concentration of IL-10 in the medium of the cocultured group was promoted $(706.33 \pm 55.59 \mathrm{pg} / \mathrm{mL})$ notably; when $\mathrm{CD}_{19}{ }^{+} \mathrm{B}$ cells cultured with the UC-MSCs were pretreated with $0.1 \mu \mathrm{g} / \mathrm{mL}$ of SDF- $1 \alpha$, the concentration of IL-10 in the coculture medium would increase $(897.74 \pm 86.52 \mathrm{pg} / \mathrm{mL})$ further (Figure $3(\mathrm{c}))$.

3.5. SDF-1 $\alpha / C X C R 4$ Participates in the Expression of miR133 in UC-MSCs. As SDF-1-CXCR4 signaling has an effect on microRNA expression [31], we next assessed the miR133 level in UC-MSCs after being incubated with the SDF$1 \alpha$. The expression of miR-133 in the UC-MSCs pretreated with $0.1 \mu \mathrm{g} / \mathrm{mL}$ of SDF- $1 \alpha$ was elevated $(1.000 \pm 0.108$ vs. 3.643 vs. 0.310 ), while when being treated by AMD3100, the receptor antagonists of CXCR4, the expression of miR133 in UC-MSCs was remarkably reduced $(1.000 \pm 0.108$ vs. 0.230 vs. 0.041 ) (Figure $4(\mathrm{a})$ ).

3.6. miR-133 Plays a Key Role in SDF-1 $\alpha$ Controlling UCMSC Proliferation and Survival. The transfection efficiency of the miR-133 inhibitor was about $70 \%$, which was evaluated by comparing the difference between the bright field and the fluorescence field of the transfected MSCs (Supplementary 4). The expression of miR-133 was remarkably reduced $(1.000 \pm 0.150$ vs. 0.260 vs. 0.041$)$ compared to the US-MSCs transfected by the miR-133 inhibitor, meaning the inhibitor successfully reduced the miR-133 level (Figure 4(b)). Apoptosis of US-MSCs was detected to study the influence of miR-133 on the function of US-MSCs. First, Annexin V/PI staining was performed to detect the apoptosis of the US-MSCs transfected by the miR-133 inhibitor after being cultured for $48 \mathrm{~h}$, and compared to the control, the apoptotic rate of the transfected-MSCs increased $(1.36 \pm 0.32 \%$ vs. $6.38 \pm 1.10 \%)$ (Figure $4(\mathrm{c}))$; then, Western blot was performed, and compared to the control, the cell cycle regulatory proteins (cyclin A1/B1) were decreased (Figure $4(\mathrm{~d})$ ), but the expression of apoptotic factors cleaved caspase-3/Bax of US-MSCs was increased (Figure 4(e)) after being transfected with the miR-133 inhibitor.

3.7. The Induction of Bregs of ITP by UC-MSCs Depends on $m i R-133$. To determine whether miR-133 plays an important role in Breg differentiation induced by UC-MSCs, 


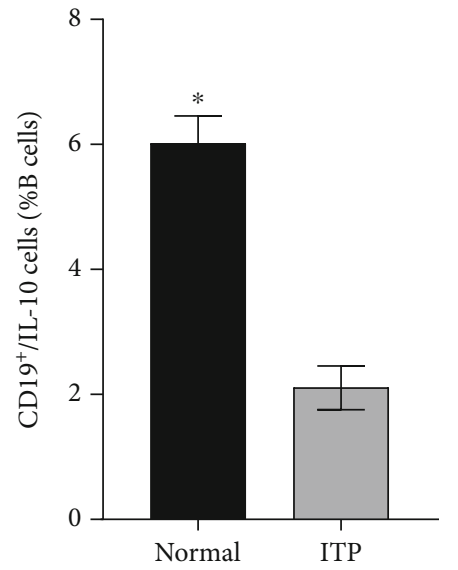

(a)

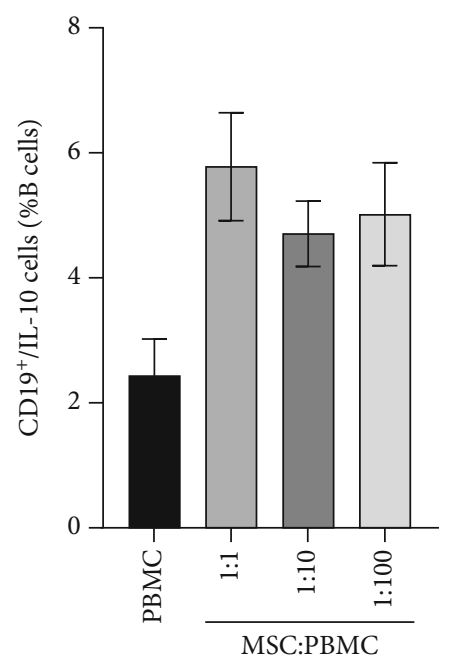

(c)

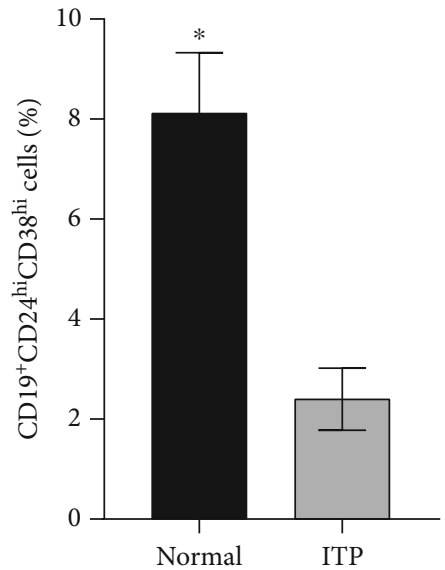

(b)

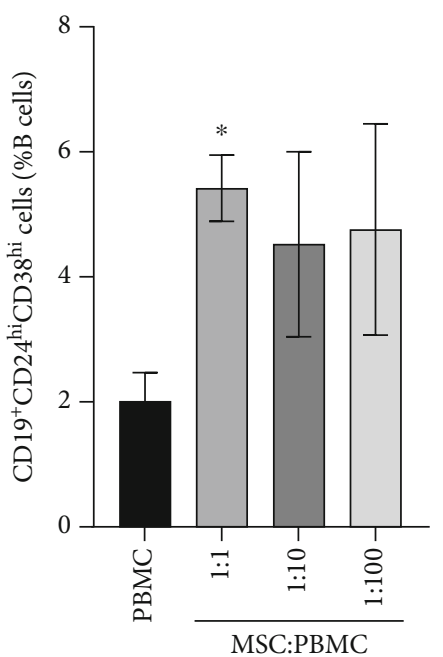

(d)

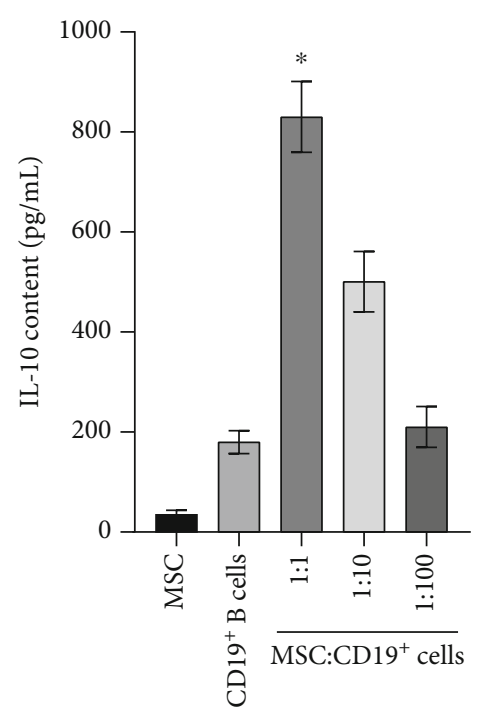

(e)

FIGURE 1: The effects of MSCs in promoting the Breg differentiation. (a) The percentages of CD $19^{+} \mathrm{CD} 24^{\text {hi }} \mathrm{CD} 38^{\mathrm{hi}} \mathrm{B}$ cells in periphery B cells from healthy person and ITP patients. (b) The percentages of IL-10-producing CD19+ $\mathrm{B}$ cells in periphery B cells from healthy person and ITP patients. (c, d) Coculture MSCs with PBMCs at the ratio of $1: 1$ can significantly increase the percentage of CD $19^{+} \mathrm{CD} 24^{\mathrm{hi}} \mathrm{CD} 38^{\mathrm{hi}} \mathrm{B}$ cells and B10 cells. (e) The concentration of IL-10 in medium promoted notably while coculture CD19 ${ }^{+} \mathrm{B}$ cells with MSC at the ratio of $1: 1$. $* P<0.05$ 


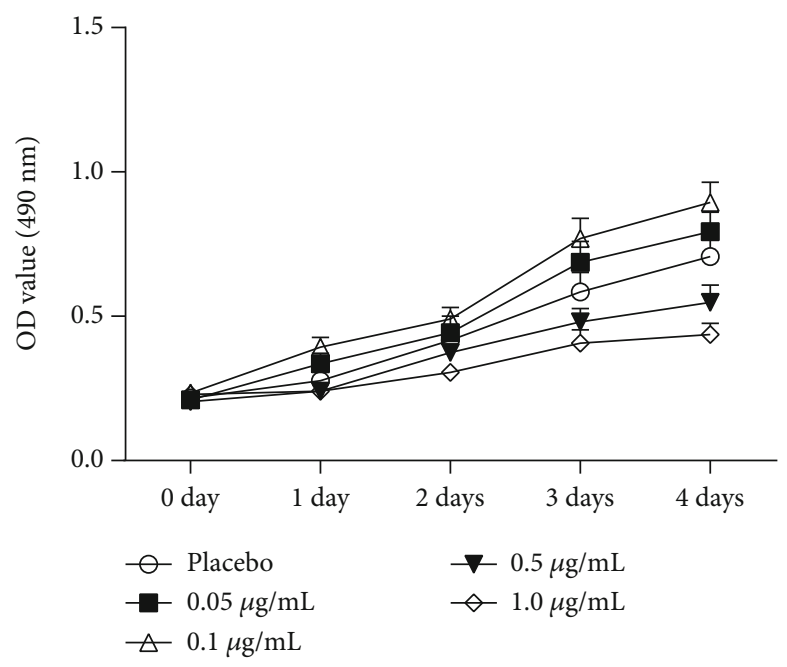

(a)

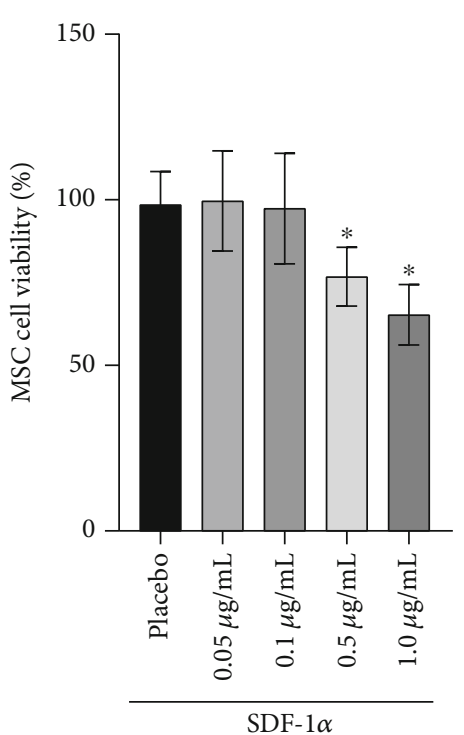

(b)

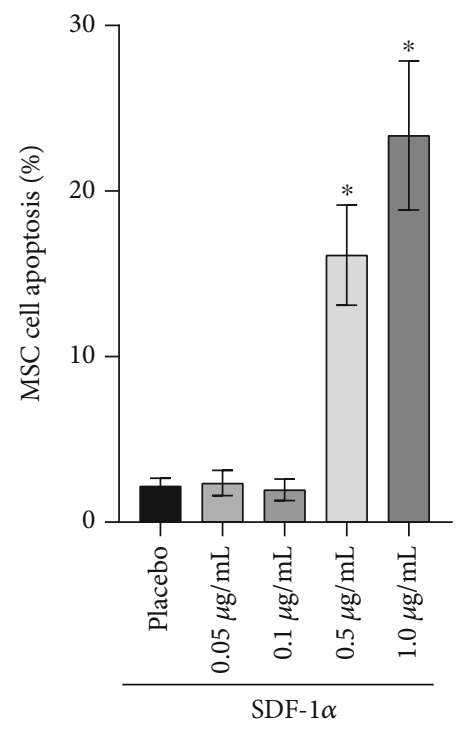

(c)

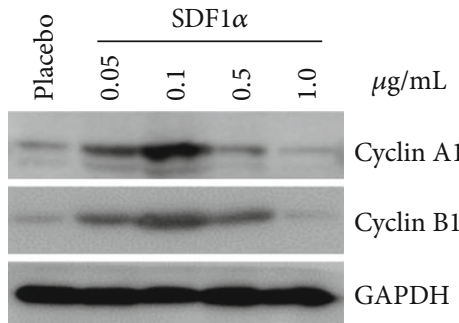

(d)

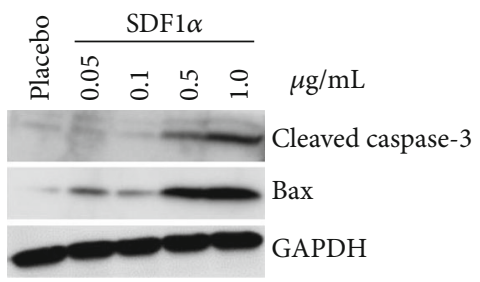

(e)

Figure 2: SDF-1 $\alpha$ affects the survival of MSC by regulating the level of cyclin A1, cyclin B1, caspase-3, and Bax. (a) The effects of different doses of SDF- $1 \alpha$ on the proliferation of MSCs. (b, c) The effects of different doses of SDF- $1 \alpha$ on the cell viability and cell apoptosis of MSCs. The viability rate and apoptotic rate had no difference at the concentrations of $0.05 \mu \mathrm{g} / \mathrm{mL}$ and $0.1 \mu \mathrm{g} / \mathrm{mL} \mathrm{SDF}-1 \alpha$; however, $0.5 \mu \mathrm{g} / \mathrm{mL}$ and $1.0 \mu \mathrm{g} / \mathrm{mL}$ SDF- $1 \alpha$ could decrease the viability rate and increase the apoptotic rate $(2.19 \pm 0.48 \%$ vs. when compared to the control). (d, e) The effects of different doses of SDF- $1 \alpha$ on the expression of cyclin A1, cyclin B1, caspase- 3 , and Bax in MSCs. ${ }^{*} P<0.05$.

PBMCs of ITP were cocultured with the US-MSCs transfected by the miR-133 inhibitor for $48 \mathrm{~h}$, and Bregs were detected; the results exhibit that $\mathrm{B} 10$ cells differentiated from ITP decreased $(3.21 \pm 0.54 \%$ vs. $5.78 \pm 0.86 \%)$ evidently compared to the nontransfected group (Figure 5(a), Supplementary 5), and correspondingly, $\mathrm{CD} 19^{+} / \mathrm{CD} 24^{\mathrm{hi}} / \mathrm{CD} 38^{\mathrm{hi}}$ cells differentiated from ITP decreased $(2.1 \pm 0.33 \%$ vs. $5.02 \pm 0.57 \%$ ) evidently (Figure 5(b), Supplementary 5). 


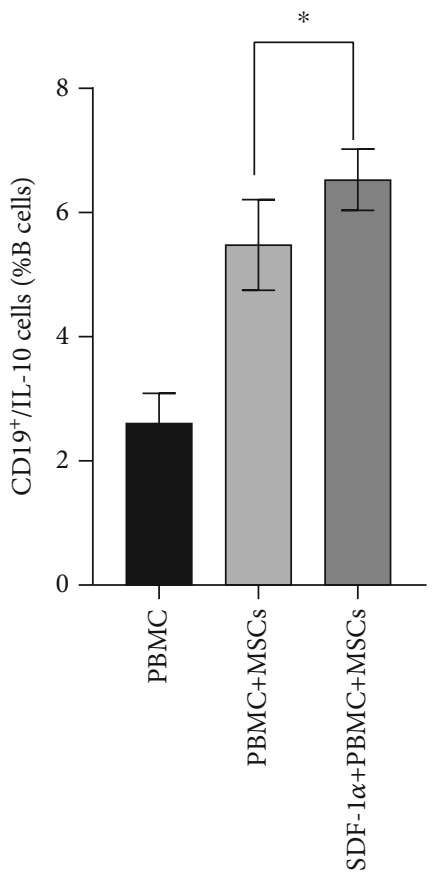

(a)

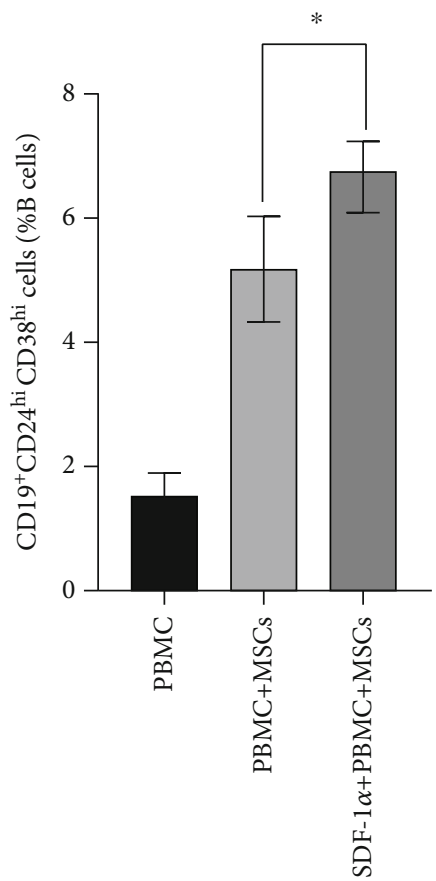

(b)

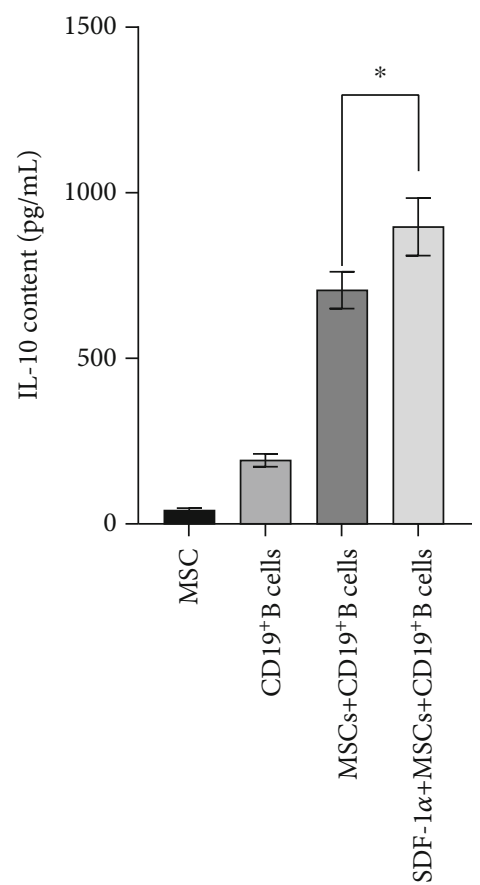

(c)

FIGURE 3: SDF-1 $\alpha$ pretreatment enhances the property of MSCs in promoting the Breg differentiation. (a,b) $0.1 \mu \mathrm{g} / \mathrm{mL}$ SDF- $1 \alpha$ promotes the effects of MSCs on IL-10-producing CD19 $\mathrm{B}$ cells or $\mathrm{CD} 19^{+} \mathrm{CD} 24^{\mathrm{hi}} \mathrm{CD} 38^{\mathrm{hi}}$ cell differentiation. (c) After being treated with $0.1 \mu \mathrm{g} / \mathrm{mL}$ SDF- $1 \alpha$, MSCs can increase the secretion of IL-10 from B cells further $(897 \pm 87 \mathrm{pg} / \mathrm{mL}$ vs. $706 \pm 55 \mathrm{pg} / \mathrm{mL}) .{ }^{*} P<0.05$.

3.8. SDF-1 $\alpha$ Facilitates MSCs to Promote Breg Differentiation through Exosomal miR-133. miR-133 exits in MSCs and MSC-derived exosomes, and the levels can be suppressed $(1.000 \pm 0.152$ vs. $0.373 \pm 0.084 \%$ and $1.000 \pm 0.143 \%$ vs. $0.280 \pm 0.088 \%$ ) by the miR-133 inhibitor (Figures 6(a) and $6(\mathrm{~b})$ ). To directly verify whether miR-133 produced by MSCs exerts its roles in an exosome-dependent manner, we used MSCs, complete MSC supernatant, exosomedepleted MSC supernatant, MSC-derived exosomes, and MSC-derived exosomes from MSCs transfected by the miR-133 inhibitor to treat ITP patient-derived PBMCs. Results showed that MSCs, complete MSC supernatant, and MSC-derived exosomes can promote $\mathrm{CD} 19^{+-}$ $\mathrm{CD} 24^{\text {hi }} \mathrm{CD} 38^{\text {hi }} \mathrm{CD} 9^{+}$B cells $(0.700 \pm 0.101$ vs. $8.200 \pm$ 


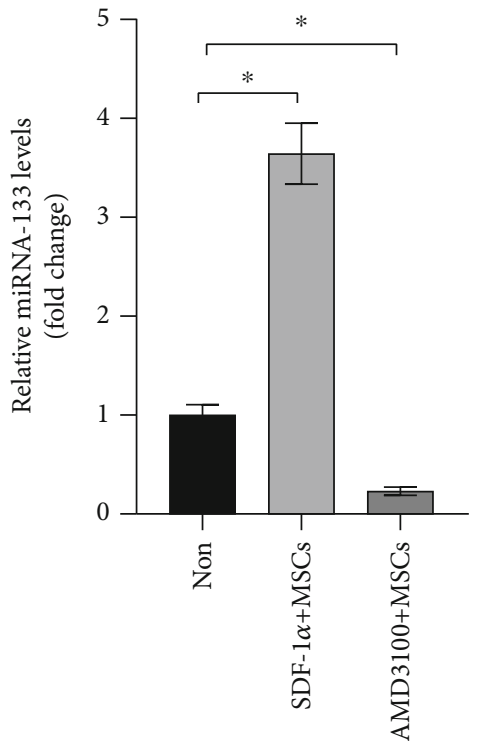

(a)

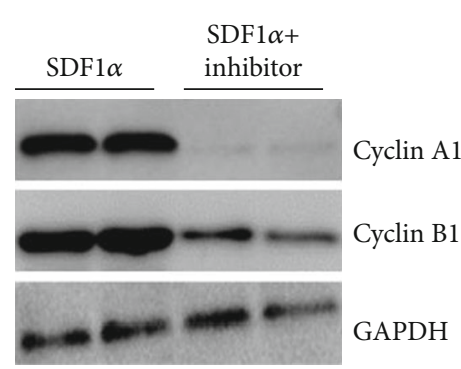

(d)

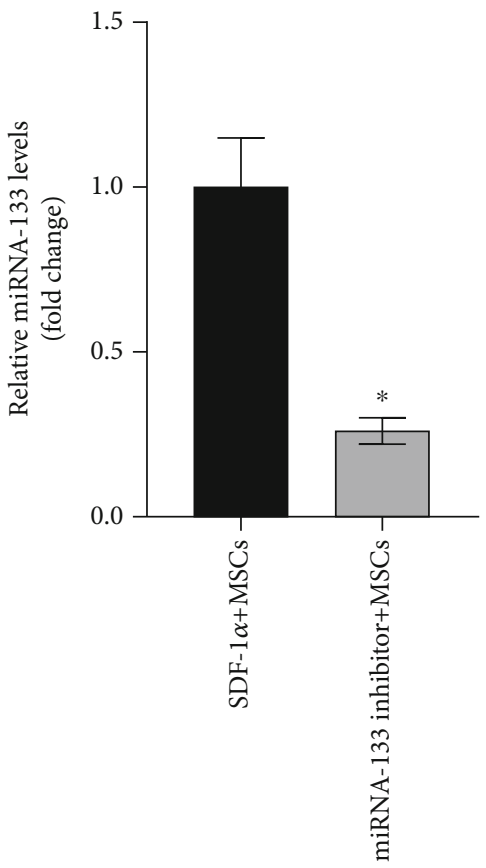

(b)

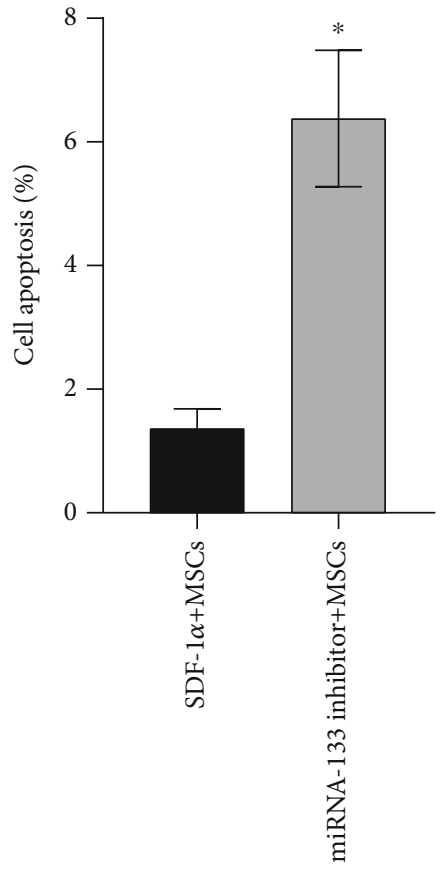

(c)

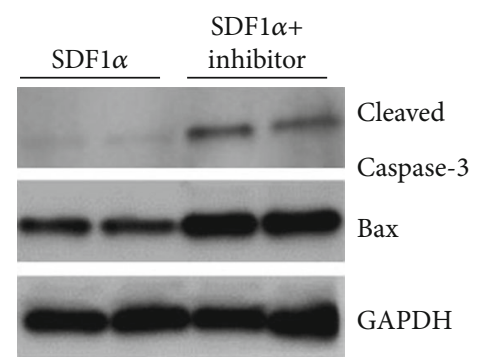

(e)

FIgURE 4: SDF-1 $\alpha$ regulates the survival of MSCs on B cells through miR-133. (a) The expression of miR-133 in MSC was increased in the presence of $0.1 \mu \mathrm{g} / \mathrm{mL}$ SDF- $1 \alpha$ but was inhibited after treating with the AMD3100. (b) The effects of miR-133 inhibitor on the expression of miR-133 in MSCs. (c) Transfected with the miR-133 inhibitor, the apoptotic rate of MSCs increased significantly. (d, e) miR-133 inhibitor influences the expression of cyclin A1, cyclin B1, cleaved caspase-3, Bax, and in MSCs. ${ }^{*} P<0.05$.

1.135 vs. $6.343 \pm 0.722$ vs. $4.907 \pm 0.645)$ and IL-10producing $\mathrm{CD}^{+} 9^{+} \mathrm{B}$ cells $(2.403 \pm 0.306$ vs. $8.320 \pm 0.887$ vs. $6.520 \pm 0.814$ vs. 6.297 vs. 0.667$)$ in ITP-derived CD19 ${ }^{+}$ $\mathrm{B}$ cells, while the exosome-depleted MSC supernatant did not show similar effects (B10: $2.403 \pm 0.306$ vs. $3.117 \pm$ $0.400, \mathrm{CD} 19^{+} \mathrm{CD} 24^{\mathrm{hi}} \mathrm{CD} 38^{\mathrm{hi}} \mathrm{CD} 19^{+}$B cells: $0.700 \pm 0.101$ vs. $1.190 \pm 0.24)$. Moreover, the miR-133 inhibitor can largely reverse the effects of MSC-derived exosomes on $\mathrm{CD} 19^{+} \mathrm{CD} 24^{\mathrm{hi}} \mathrm{CD} 38^{\mathrm{hi}} \mathrm{CD} 9^{+} \mathrm{B}$ cells $(0.700 \pm 0.101 \%$ vs. $1.860 \pm 0.265 \%)$ and IL-10-producing $\mathrm{CD}^{+} 9^{+} \mathrm{B}$ cell $(2.403 \pm 0.306 \%$ vs. $4.05 \pm 0.49 \%)$ generation (Figures $6(\mathrm{c})$ and 6(d), Supplementary 6-7).

\section{Discussion}

There are no specific intracellular or cell surface markers of Bregs yet [3]; however, IL-10 is a potent negative immunomodulatory factor, so the IL-10-secreting B cells are described as Bregs that have the similar immunosuppressive effects as Tregs [32]. Scholars further described the human
Bregs within the $\mathrm{CD} 19^{+} \mathrm{CD} 24^{\text {hi }} \mathrm{CD} 38^{\text {hi }}$ immature transitional $\mathrm{B}$ cells that this subset has the ability to reduce $\mathrm{CD}^{+}{ }^{+}$T-cell activation via production of the IL-10 and CD80/CD86 pathway $[33,34]$. Bregs are potent suppressive lymphocytes for maintaining peripheral tolerance and abating pathogenic immune responses [2]. The $\mathrm{CD} 19^{+-}$ $\mathrm{CD} 24^{\mathrm{hi}} \mathrm{CD} 38^{\text {hi }}$ subset produced less IL-10 and had reduced suppressive activity, suggesting the deficiency of Bregs in SLE [35]. Li et al. had found that the Bregs are deficient in active disease, and therapy that raises platelet counts also rescues the underachieving $\mathrm{B}$-cell subset [4]. Our results showed the notable reduction of $\mathrm{CD} 19^{+} \mathrm{CD} 24^{\text {hi }} \mathrm{CD} 38^{\text {hi }}$ and IL-10-expressing (B10) cell subsets in peripheral blood of ITP, further verifying the abnormal Bregs in ITP [3]. This implies that the decrease of Bregs can lead to the overactivation of autoreactive cells and cause or aggravate the platelet destruction of ITP.

MSCs can not only directly restrain proliferation of the effector B cells [11-13, 36] but also induce differentiation of the $\mathrm{CD} 19^{+} \mathrm{CD}^{+} \mathrm{B}$ cell subset of patients with graft versus 


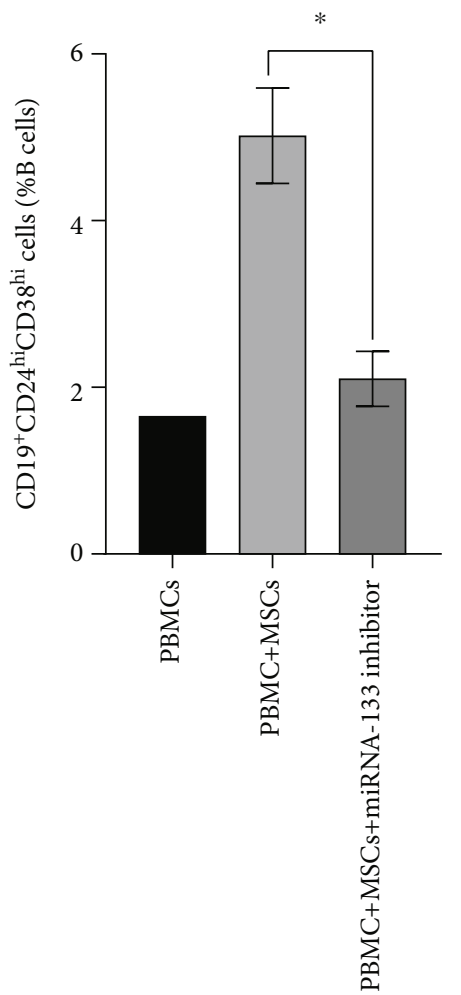

(a)

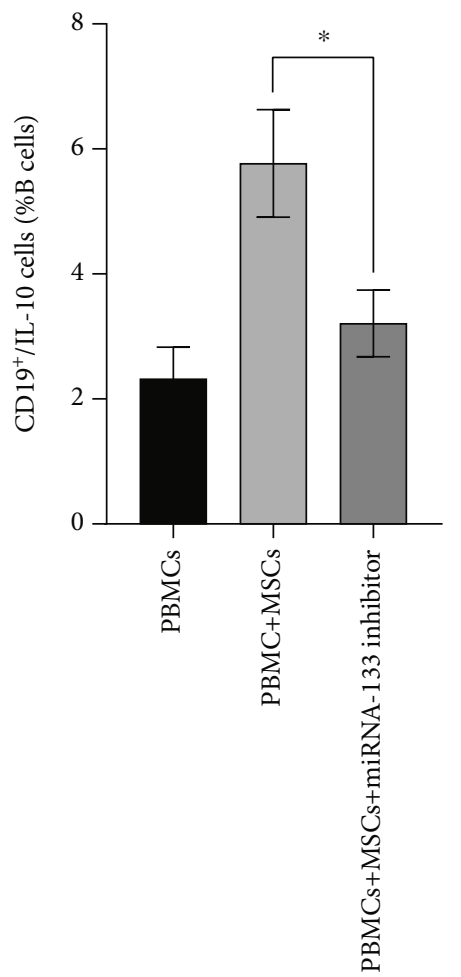

(b)

FIGURE 5: SDF-1 $\alpha$ regulates the effects of MSCs on B cells through changing the miR-133 level. (a) Transfected by miR-133 inhibitor, the ability of MSCs to facilitate $\mathrm{CD} 19^{+} \mathrm{CD} 24^{\text {hi }} \mathrm{CD} 38^{\text {hi }} \mathrm{CD} 19^{+} \mathrm{B}$ cells was depressed. (b) Transfected by miR-133 inhibitor, the ability of MSCs to facilitate IL-10-producing $\mathrm{CD} 19^{+} \mathrm{B}$ cells was depressed. ${ }^{*} P<0.05$.

host disease, which secretes IL-10, thus being recognized as Bregs [18]. After being cocultured with UC-MSCs, we found that the reduced proportion of both $\mathrm{CD} 19^{+} \mathrm{CD} 24^{\mathrm{hi}} \mathrm{CD} 38^{\text {hi }}$ and $\mathrm{B} 10$ cells of ITP increased significantly, suggesting UC-MSCs can induce immune tolerance in ITP treatment by mediating $B$ cell subgroup changes. However, because of the obstacles in migration and survival of MSCs, there still remain many difficulties for MSC treatment. In great part, the therapeutic effect of MSCs depends on the retention time in the body and tissue [37]. As a chemokine secreted by MSCs, SDF- $1 \alpha$ can modulate angiogenesis and stem cell recruitment in regenerative process of MSCs [38] and can direct MSC migration in response to inflammatory and/or hypoxic stimuli [39]. It has been demonstrated that SDF$1 \alpha$ and its specific receptor CXCR- 4 play key roles on MSC migration and survival [40]. Therefore, we observed the effect of different concentrations of SDF- $1 \alpha$ on UC-MSCs and also found that different concentrations of SDF- $1 \alpha$ led to different proliferations, survival, and apoptosis results of UC-MSCs and that the lower doses of $0.05 \mu \mathrm{g} / \mathrm{mL}$ and $0.1 \mu \mathrm{g} / \mathrm{mL}$ of SDF- $1 \alpha$ can promote the proliferation of UCMSCs, while the higher doses of $0.5 \mu \mathrm{g} / \mathrm{mL}$ and $1.0 \mu \mathrm{g} / \mathrm{mL}$ of SDF- $1 \alpha$ can promote the apoptosis but inhibit the proliferation and reduce the survival rate of UC-MSCs [29]. However, the mechanism is not clear, so further research is needed to elucidate such differences. Next, $0.1 \mu \mathrm{g} / \mathrm{mL}$ concentration of SDF- $1 \alpha$ was selected to study whether SDF-
$1 \alpha /$ CXCR 4 can directly affect the induction of Bregs by UB-MSCs. The results showed that the SDF- $1 \alpha$-stimulated UB-MSCs can further upregulate the proportion of Bregs in ITP, and the IL-10 content in the supernatant also increased much more. These suggest that $0.1 \mu \mathrm{g} / \mathrm{mL}$ of SDF- $1 \alpha$ could be used as preconditioning for UB-MSC treatment to enhance the immune regulatory effect in ITP.

MicroRNAs (miRNAs) are a series of single-stranded short nucleotides that are involved in gene expression and regulation after transcription in eukaryotic cells and are very important in the realization of many biological functions [41]. The increased expression of miRNAs can enhance the tolerance of MSCs to hypoxia, while knocking down miRNAs will increase the apoptosis rate of MSCs under hypoxia stimulation [42]. Among a large number of miRNAs, miRNA-133 is a kind of miRNA that participates in a variety of cell functions and has an important influence on the proliferation, as well as differentiation, of MSCs [43]. Chen et al. [23] found that the rats transplanted with miR-133overexpressing MSCs displayed more improved cardiac function after acute myocardial infarction. Therefore, we supposed that SDF- $1 \alpha$ enhances the cell function by elevating the miR-133 expression in MSCs. So, we detected the miRNA-133 level with $0.1 \mu \mathrm{g} / \mathrm{mL}$ of SDF- $1 \alpha$ in the control of UC-MSCs. First, we found that SDF- $1 \alpha$ can mediate the elevation of miRNA-133 in MSCs and lead to less apoptosis. The role of the SDF- $1 \alpha / \mathrm{CXCR} 4$ axis in the survival and 


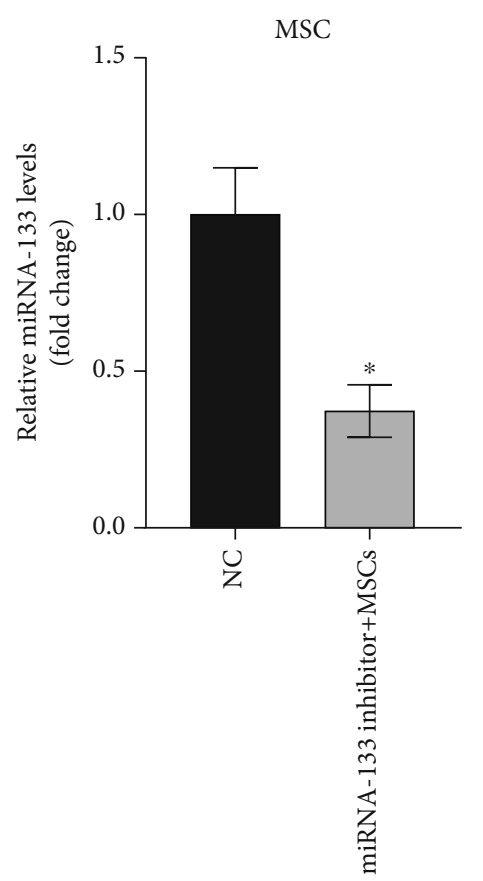

(a)

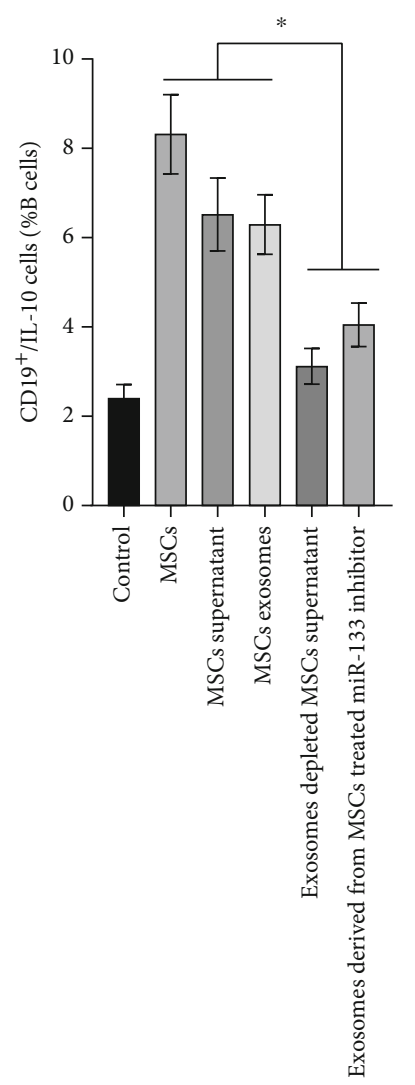

(c)

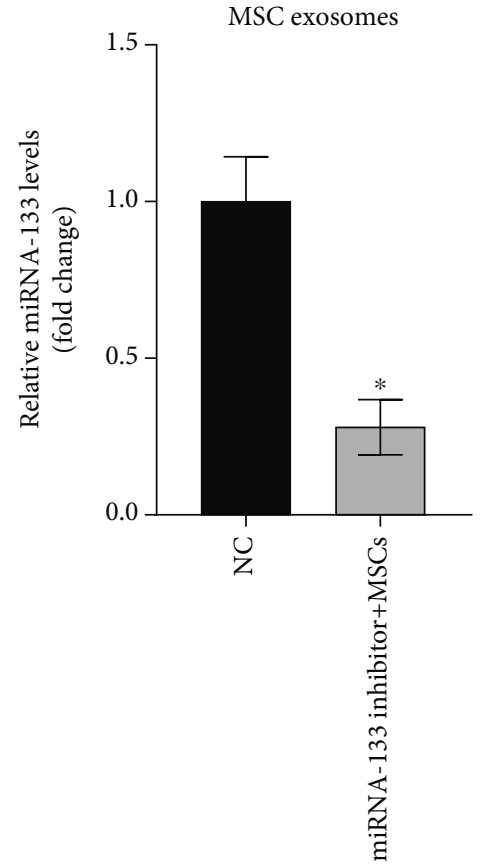

(b)

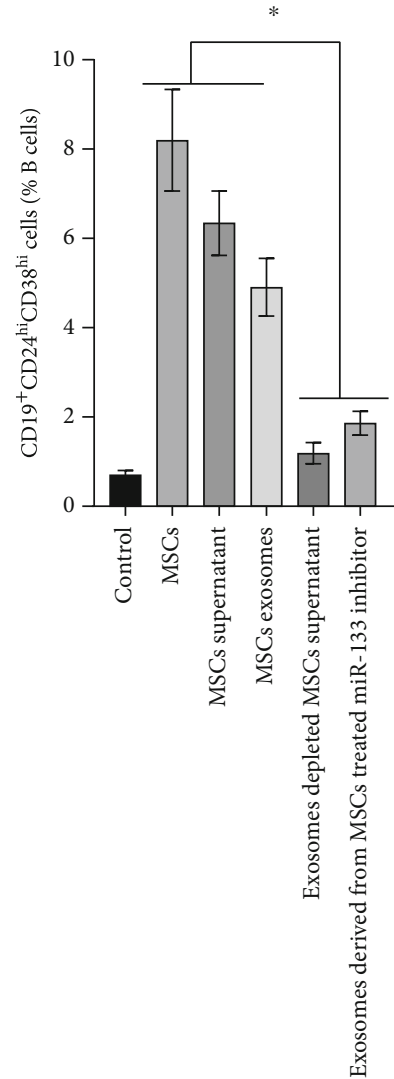

(d)

FIGURE 6: miR-133 mediates the effects of MSCs on B cells dependent on exosome-based delivery. (a, b) Transfected with the miRNA-133 inhibitor, the miRNA-133 level was significantly depressed in MSCs or exosomes. (c, d) When PBMCs are cultured with the MSCs, MSC supernatant, or MSC exosomes, the percentage of $\mathrm{CD} 19^{+} \mathrm{CD} 24^{\mathrm{hi}} \mathrm{CD} 38^{\mathrm{hi}} \mathrm{CD} 19^{+} \mathrm{B}$ cells and IL-10-producing CD $19^{+} \mathrm{B}$ cells will increase, but this phenomenon was reversed when the MSCs were pretreated with the miRNA-133 inhibitor or the MSC supernatants were depleted of exosomes. ${ }^{*} P<0.05$. 
function of MSCs has been achieved by influencing miRNA expression [44], and we also found that when treated with AMD3100, the inhibitor of CXCR4, the expression of miRNA-133 in MSCs decreased prominently. Second, the apoptotic rate of MSCs transfected with the miRNA-133 inhibitor significantly increased, and the apoptin-cleaved caspase- 3 and Bax in MSCs also increased, while the cyclins in MSCs decreased. These confirm that miRNA-133 plays a key role in controlling the proliferation and survival of UCMSCs by SDF- $1 \alpha$. We further assess the immunological function of MSCs after depressing the miR-133 level, and the results showed that the expression of miR-133 in UCMSCs was prevented by transfecting the miRNA-133 inhibitor. Compared to the nontransfected UC-MSCs, when miR133 inhibitor transfected UC-MSCs cocultured with PBMCs of ITP, the induction of B10 cells decreased obviously; correspondingly, the induction of $\mathrm{CD} 19^{+} / \mathrm{CD} 24^{\mathrm{hi}} / \mathrm{CD} 38^{\mathrm{hi}} \mathrm{B}$ cells also decreased remarkably. These results indicate that the reduction of miRNA-133 in UC-MSCs leads to the decreased differentiation of Bregs. On the one hand, it can be explained that the ability of SDF- $1 \alpha$ to promote the proliferation and survival of MSCs is achieved by regulating miRNA-133 expression; on the other hand, it also proves that SDF- $1 \alpha$ enhances the expression of miRNA-133 by interacting with CXCR4, thus promoting the differentiation of Bregs in ITP.

As the Transwell was used to coculture the MSCs with the PBMCs, the cellular interactions should be induced by the soluble mediators. Exosomes are small membrane vesicles participating in intercellular communication and can realize their function by transmitting the exosomal miRNAs [45]. We demonstrated that SDF- $1 \alpha$ can elevate the miRNA-133 expression of MSCs, as well as the exosomal miRNA-133 secreted by MSCs. The depletion of exosomes in the culture supernatant resulted in the significant reduction of Bregs. This result indicates that exosomal miRNA133 secreted by MSCs can increase the polarization of Bregs. Although MSCs have been shown to inhibit immune cell activation, reduce inflammatory cytokines, and induce autoimmune tolerance and have already been used as treatment methods [46], the exact regulating mechanism on how SDF- $1 \alpha$ controls MSCs in inducing Breg differentiation of ITP still requires more and intensive research, especially involving with miRNA-133 expression.

\section{Conclusions}

UC-MSCs could effectively enhance the decreased proportion of Bregs from ITP; different doses of SDF- $1 \alpha$ have different effects on the proliferation, apoptosis, and survival of UC-MSCs, and at appropriate concentrations, SDF- $1 \alpha$ may further promote the proliferating and survival ability of UC-MSCs and improve the production of Bregs induced by UC-MSCs through controlling the miRNA-133 expression in the exosomes, which displays a novel solution in improving the immunoregulatory capacity of MSCs for ITP management.

\section{Data Availability}

The data used to support the findings of this study are available from the corresponding author upon request.

\section{Ethical Approval}

PBMC preparation for the study was isolated from the peripheral blood of ITP patients and healthy adult volunteers after written informed consent and ethics committee approval (BYL20170203), and the study was approved by the local ethics committee and adhered to the tenets of the Declaration of Helsinki.

\section{Consent}

The patients gave written informed consent for the research studies.

\section{Conflicts of Interest}

The authors declare that they have no competing interests.

\section{Authors' Contributions}

Zhe Chen and Shufen Zhou contributed equally to this work.

\section{Acknowledgments}

We appreciate Dr. Tianxing Chen (Central laboratory, Spunolin Biotechnology Co., Ltd.) and Prof. Xi Chen (Central Laboratory, Baoan People's Hospital) for their assistance in the laboratory. This work was supported by grants from the National Natural Science Foundation of China (No. 81270577); the Science and Technology Innovation Foundation of Shenzhen, China (No. JCYJ20160427191026117); the Youth Fund Project of Baoan People's Hospital Group (First Hospital), Shenzhen, China (No. 2018A008, No. 2018B007); and the Construction Units of Key Specialties in Clinical Medicine, Baoan District, Shenzhen, China (No. 8, 2142018, Health Commission of Baoan, Shenzhen City).

\section{Supplementary Materials}

Supplementary 1: the morphology of the MSC and the FACS analysis for the surface markers. Supplementary 2: the original picture of FACS in Figures 1(a) and 1(b). Supplementary 3: the original picture of FACS in Figures 3(a) and 3(b). Supplementary 4: morphology of MSCs observed under inverted fluorescence microscope. Supplementary 5: the original picture of FACS in Figures 5(a) and 5(b). Supplementary 6-7: the original picture of FACS in Figures 6(c) and 6(d). (Supplementary Materials)

\section{References}

[1] S. Audia, M. Mahévas, M. Samson, B. Godeau, and B. Bonnotte, "Pathogenesis of immune thrombocytopenia," Autoimmunity Reviews, vol. 16, no. 6, pp. 620-632, 2017. 
[2] C. Mauri and A. Bosma, "Immune regulatory function of B cells," Annual Review of Immunology, vol. 30, no. 1, pp. 221241, 2012.

[3] I. Kalampokis, A. Yoshizaki, and T. F. Tedder, "IL-10-producing regulatory B cells (B10 cells) in autoimmune disease," Arthritis research \& therapy, vol. 15, Supplement 1, p. S1, 2013.

[4] X. Li, H. Zhong, W. Bao et al., "Defective regulatory B-cell compartment in patients with immune thrombocytopenia," Blood, vol. 120, no. 16, pp. 3318-3325, 2012.

[5] B. Parekkadan and J. M. Milwid, "Mesenchymal stem cells as therapeutics," Annual Review of Biomedical Engineering, vol. 12, no. 1, pp. 87-117, 2010.

[6] M. Najar, G. Raicevic, H. Fayyad-Kazan, D. Bron, M. Toungouz, and L. Lagneaux, "Mesenchymal stromal cells and immunomodulation: a gathering of regulatory immune cells," Cytotherapy, vol. 18, no. 2, pp. 160-171, 2016.

[7] L. L. de Castro, M. Lopes-Pacheco, D. J. Weiss, F. F. Cruz, and P. Rocco, "Current understanding of the immunosuppressive properties of mesenchymal stromal cells," Journal of Molecular Medicine (Berlin, Germany), vol. 97, no. 5, pp. 605618, 2019.

[8] A. Dorronsoro, I. Ferrin, J. M. Salcedo et al., "Human mesenchymal stromal cells modulate T-cell responses through TNF$\alpha$ - mediated activation of NF- $\kappa \mathrm{B}$," European Journal of Immunology, vol. 44, no. 2, pp. 480-488, 2014.

[9] X. Li, Y. Chen, X. Liu et al., "Tim3/Gal9 interactions between T cells and monocytes result in an immunosuppressive feedback loop that inhibits Th1 responses in osteosarcoma patients," International Immunopharmacology, vol. 44, pp. 153-159, 2017.

[10] J. Wu, C. Ji, F. Cao, H. Lui, B. Xia, and L. Wang, "Bone marrow mesenchymal stem cells inhibit dendritic cells differentiation and maturation by microRNA-23b," Bioscience Reports, vol. 37, no. 2, 2017.

[11] D. Chatterjee, D. M. Tufa, H. Baehre, R. Hass, R. E. Schmidt, and R. Jacobs, "Natural killer cells acquire CD73 expression upon exposure to mesenchymal stem cells," Blood, vol. 123, no. 4, pp. 594-595, 2014.

[12] K. Chao, S. Zhang, Y. Qiu et al., "Human umbilical cordderived mesenchymal stem cells protect against experimental colitis via CD5(+) B regulatory cells," Stem Cell Research \& Therapy, vol. 7, no. 1, p. 109, 2016.

[13] Y. Peng, X. Chen, Q. Liu et al., "Mesenchymal stromal cells infusions improve refractory chronic graft versus host disease through an increase of $\mathrm{CD} 5+$ regulatory $\mathrm{B}$ cells producing interleukin 10," Leukemia, vol. 29, no. 3, pp. 636-646, 2015.

[14] D. Mougiakakos, R. Jitschin, C. C. Johansson, R. Okita, R. Kiessling, and K. Le Blanc, "The impact of inflammatory licensing on heme oxygenase-1-mediated induction of regulatory $\mathrm{T}$ cells by human mesenchymal stem cells," Blood, vol. 117, no. 18, pp. 4826-4835, 2011.

[15] K. English, J. M. Ryan, L. Tobin, M. J. Murphy, F. P. Barry, and B. P. Mahon, "Cell contact, prostaglandin E (2) and transforming growth factor beta 1 play non-redundant roles in human mesenchymal stem cell induction of CD4 +CD25(high) forkhead box P3+ regulatory T cells," Clinical and Experimental Immunology, vol. 156, no. 1, pp. 149-160, 2009.

[16] F. Luk, S. F. de Witte, S. S. Korevaar et al., "Inactivated mesenchymal stem cells maintain immunomodulatory capacity," Stem Cells and Development, vol. 25, no. 18, pp. 1342-1354, 2016.
[17] I. Rasmusson, K. Le Blanc, B. Sundberg, and O. Ringdén, "Mesenchymal stem cells stimulate antibody secretion in human B cells," Scandinavian Journal of Immunology, vol. 65, no. 4, pp. 336-343, 2007.

[18] M. Krampera, L. Cosmi, R. Angeli et al., "Role for interferongamma in the immunomodulatory activity of human bone marrow mesenchymal stem cells," Stem Cells, vol. 24, no. 2, pp. 386-398, 2006.

[19] N. G. Frangogiannis, "The stromal cell-derived factor$1 /$ CXCR4 axis in cardiac injury and repair*," Journal of the American College of Cardiology, vol. 58, no. 23, pp. 24242426, 2011.

[20] L. A. Marquez-Curtis and A. Janowska-Wieczorek, "Enhancing the migration ability of mesenchymal stromal cells by targeting the SDF-1/CXCR4 axis," BioMed Research International, vol. 2013, Article ID 561098, 15 pages, 2013.

[21] H. Gao, W. Priebe, J. Glod, and D. Banerjee, "Activation of signal transducers and activators of transcription 3 and focal adhesion kinase by stromal cell-derived factor 1 is required for migration of human mesenchymal stem cells in response to tumor cell-conditioned medium," Stem Cells, vol. 27, no. 4, pp. 857-865, 2009.

[22] B. Yu, X. Zhang, and X. Li, "Exosomes derived from mesenchymal stem cells," International Journal of Molecular Sciences, vol. 15, no. 3, pp. 4142-4157, 2014.

[23] Y. Chen, Y. Zhao, W. Chen et al., "MicroRNA-133 overexpression promotes the therapeutic efficacy of mesenchymal stem cells on acute myocardial infarction," Stem Cell Research of Therapy, vol. 8, no. 1, p. 268, 2017.

[24] D. Provan, R. Stasi, A. C. Newland et al., "International consensus report on the investigation and management of primary immune thrombocytopenia," Blood, vol. 115, no. 2, pp. 168$186,2010$.

[25] Thrombosis and Hemostasis Group, Hematology Society, Chinese Medical Association, "Consensus of Chinese experts on diagnosis and treatment of adult primary immune thrombocytopenia (version 2016)," Zhonghua Xue Ye Xue Za Zhi, vol. 37, no. 2, pp. 89-93, 2016.

[26] Y. F. Han, R. Tao, T. J. Sun, J. K. Chai, G. Xu, and J. Liu, "Optimization of human umbilical cord mesenchymal stem cell isolation and culture methods," Cytotechnology, vol. 65, no. 5, pp. 819-827, 2013.

[27] Y. Mori, J. Ohshimo, T. Shimazu et al., "Improved explant method to isolate umbilical cord-derived mesenchymal stem cells and their immunosuppressive properties," Tissue Engineering. Part C, Methods, vol. 21, no. 4, pp. 367-372, 2015.

[28] A. Otte, V. Bucan, K. Reimers, and R. Hass, "Mesenchymal stem cells maintain long-term in vitro stemness during explant culture," Tissue Engineering. Part C, Methods, vol. 19, no. 12, pp. 937-948, 2013.

[29] Y. Qin, Z. Zhou, F. Zhang et al., "Induction of regulatory Bcells by mesenchymal stem cells is affected by SDF- $1 \alpha$ CXCR7," Cellular Physiology and Biochemistry, vol. 37, no. 1, pp. 117-130, 2015.

[30] Y.Zhuang, D. Li, J. Fu, Q. Shi, Y. Lu, and X. Ju, "Comparison of biological properties of umbilical cord-derived mesenchymal stem cells from early and late passages: immunomodulatory ability is enhanced in aged cells," Molecular Medicine Reports, vol. 11, no. 1, pp. 166-174, 2015. 
[31] L. V. Rhodes, M. R. Bratton, Y. Zhu et al., "Effects of SDF-1CXCR4 signaling on microRNA expression and tumorigenesis in estrogen receptor-alpha (ER- $\alpha$ )-positive breast cancer cells," Experimental Cell Research, vol. 317, no. 18, pp. 2573-2581, 2011.

[32] J. M. Lykken, K. M. Candando, and T. F. Tedder, "Regulatory B10 cell development and function," International Immunology, vol. 27, no. 10, pp. 471-477, 2015.

[33] J. D. Bouaziz, S. Calbo, M. Maho-Vaillant et al., "IL-10 produced by activated human B cells regulates CD4(+) T-cell activation in vitro," European Journal of Immunology, vol. 40, no. 10, pp. 2686-2691, 2010.

[34] Y. Iwata, T. Matsushita, M. Horikawa et al., "Characterization of a rare IL-10-competent B-cell subset in humans that parallels mouse regulatory B10 cells," Blood, vol. 117, no. 2, pp. 530541, 2011.

[35] P. A. Blair, L. Y. Noreña, F. Flores-Borja et al., "CD19 $9^{+-}$ $\mathrm{CD} 24^{\text {hi }} \mathrm{CD} 38^{\text {hi }} \mathrm{B}$ cells exhibit regulatory capacity in healthy individuals but are functionally impaired in systemic lupus erythematosus patients," Immunity, vol. 32, no. 1, pp. 129140, 2010.

[36] P. Luz-Crawford, F. Djouad, K. Toupet et al., "Mesenchymal stem cell-derived interleukin 1 receptor antagonist promotes macrophage polarization and inhibits B cell differentiation," Stem Cells, vol. 34, no. 2, pp. 483-492, 2016.

[37] A. Lebouvier, A. Poignard, M. Cavet et al., "Development of a simple procedure for the treatment of femoral head osteonecrosis with intra-osseous injection of bone marrow mesenchymal stromal cells: study of their biodistribution in the early time points after injection," Stem Cell Research \& Therapy, vol. 6, no. 1, p. 68, 2015.

[38] J. Reiter, S. Drummond, I. Sammour et al., "Stromal derived factor-1 mediates the lung regenerative effects of mesenchymal stem cells in a rodent model of bronchopulmonary dysplasia," Respiratory Research, vol. 18, no. 1, p. 137, 2017.

[39] Y. Yu, R. X. Wu, L. N. Gao, Y. Xia, H. N. Tang, and F. M. Chen, "Stromal cell-derived factor-1-directed bone marrow mesenchymal stem cell migration in response to inflammatory and/or hypoxic stimuli," Cell Adhesion \& Migration, vol. 10, no. 4, pp. 342-359, 2016.

[40] A. Cai, R. Qiu, L. Li et al., "Atorvastatin treatment of rats with ischemia-reperfusion injury improves adipose-derived mesenchymal stem cell migration and survival via the SDF1 $\alpha$ /CXCR-4 axis," PLoS One, vol. 8, no. 12, article e79100, 2013.

[41] D. P. Bartel, "Metazoan MicroRNAs," Cell, vol. 173, no. 1, pp. 20-51, 2018.

[42] C. Y. Lee, S. Shin, J. Lee et al., "MicroRNA-mediated downregulation of apoptosis signal-regulating kinase 1 (ASK1) attenuates the apoptosis of human mesenchymal stem cells (MSCs) transplanted into infarcted heart," International journal of molecular sciences, vol. 17, no. 10, p. 1752, 2016.

[43] H. Lv, Y. Sun, and Y. Zhang, "miR-133 is involved in estrogen deficiency-induced osteoporosis through modulating osteogenic differentiation of mesenchymal stem cells," Medical Science Monitor, vol. 21, pp. 1527-1534, 2015.
[44] T. Sun, X. Li, H. Song et al., "miR-146a aggravates LPSinduced inflammatory injury by targeting CXCR4 in the articular chondrocytes," Cellular Physiology and Biochemistry, vol. 44, no. 4, pp. 1282-1294, 2017.

[45] C. Bang, S. Batkai, S. Dangwal et al., "Cardiac fibroblastderived microRNA passenger strand-enriched exosomes mediate cardiomyocyte hypertrophy," The Journal of Clinical Investigation, vol. 124, no. 5, pp. 2136-2146, 2014.

[46] F. See, T. Seki, P. J. Psaltis et al., "Therapeutic effects of human STRO-3-selected mesenchymal precursor cells and their soluble factors in experimental myocardial ischemia," Journal of Cellular and Molecular Medicine, vol. 15, no. 10, pp. 21172129, 2011. 